\title{
Embodying human rights in \#FeesMustFall? Contributions from an indecent theology
}

\begin{abstract}
Authors:
Lisa Grassow ${ }^{1}$

Clint Le Bruyns ${ }^{1}$

Affiliations:

${ }^{1}$ Theology and Development Programme, University of KwaZulu-Natal, South Africa

Corresponding author:

Clint Le Bruyns,

lebruyns@ukzn.ac.za

Dates:

Received: 28 Aug. 2017

Accepted: 03 Sept. 2017

Published: 15 Nov. 2017

How to cite this article: Grassow, L. \& Le Bruyns, C., 2017, 'Embodying human rights in \#FeesMustFall? Contributions from an indecent theology', HTS Teologiese Studies/ Theological Studies 73(3), a4799. https://doi.org/ 10.4102/hts.v73i3.4799

\section{Copyright:}

(c) 2017. The Authors. Licensee: AOSIS. This work is licensed under the Creative Commons Attribution License.
\end{abstract}

This article focuses on the \#FeesMustFall (FMF) movement and the question of a human rights culture. It provides evidence from the specific context of FMF at the University of KwaZulu-Natal, Pietermaritzburg, which exposes human rights abuses and violence to the dignity of protesting students. To advance a human rights culture within the higher education sector in the context of FMF, the article highlights the role of theology - 'indecent theology' (as espoused by Marcella Althaus-Reid) - in revealing the problem and promise of higher education institutions in the quest for a more liberating and responsible society. It is only through interrogating the narratives that sustain the current university structures - and continue to oppress the poor and the marginalised that South Africa will be able to begin to construct a society that is respective of the rights of all.

\section{Introduction}

Human rights are universal to all people; however, while legislation may provide for the protection of rights, it does not guarantee that these rights are experienced by all people. Instead, what is needed is the development of a culture that is protective and respective of the human rights of all. The recently published Veracruz Declaration (Talloires Network 2017) is an articulation of the desire for a socially responsible university culture that is respective of human rights. However, as demonstrated in the recent \#FeesMustFall (FMF) protests, this culture is not an entrenched part of university or institutional culture. While there has been some attempt at creative engagement with the FMF protests in an attempt to foster a socially responsible university environment, this engagement has not come from the institutional powers but rather from civil society (and some theologians). As a result, the FMF protests have evidenced a university institutional culture that is not conducive to the nurturing of a human rights culture. Furthermore, the theologian, Marcella Althaus-Reid's, Indecent Theology offers insights that might be applied to the FMF narrative, with specific attention given to the University of KwaZulu-Natal (UKZN) Pietermaritzburg (PMB) campus. Furthermore, this 'Indecent Theology' offers insights into the dehumanising consequences should we not take seriously the need to create a human rights culture in our university communities.

\section{Human rights}

Ishay (2004) writes that:

human rights are rights held by individuals simply because they are part of the human species. They are rights shared equally by everyone regardless of sex, race, nationality, and economic background, they are universal in content. (p. 2)

The idea of human rights is one that recognises the individual moral agency of each person as well as showing concern for their vulnerability (Palm 2015:21). Furthermore, while human rights are about the agency and vulnerability of each individual, it also concerns the community or human collective. Regardless of exactly how we define human rights, all definitions have in common the understanding that human rights are universal to all humanity, and at the core of this recognition is the ideal that each and every person has the right to human dignity (An-Na'im \& Deng 1990:10). ${ }^{1}$

However, while human rights are enshrined within legislation such as the Universal Declaration of Human Rights, simply legalising rights is not enough to ensure that they become part of the lived reality of all people (Gibson 2004:10; Van Der Ven, Dreyer \& Pieterse 2000:114). Gibson (2004:10) notes that law in itself cannot and does not guarantee human rights, but that it is entirely possible that these same human rights can be lost through legal means. Furthermore, there is the

1.For more in depth analysis of the emergence of human rights, see lshay (2008) and Cmiel (2004)

Note: The collection entitled 'Spirit rising: tracing movements of justice', forms part of the 'Faith in the City' research project, hosted by the Centre for Contextual Ministry in the Faculty of Theology, University of Pretoria. Some of the articles were papers presented at the Biennial Consultation on Urban Ministry, hosted by the Institute for Urban Ministry, in collaboration with other organizations, from 17-20 August 2016. The theme of this Consultation was '\#We must rise: healers-dreamers-jesters'. 
risk that these rights will, and often do, remain nothing more than abstract ideals and political rhetoric, never taking form at the grass roots level in the daily lives of normal people (Palm 2015:1). In order for a society to become one that experiences the lived reality of human rights, along with their ideals of human dignity and freedom for all, that society has to begin to move past simply having a legal document protecting rights. It has to begin to move into a place where those rights are embodied and lived out, thus becoming part of the culture of society. In short, a society that invests in the promotion of human rights must find a way to transition from human rights as legal ideals into creating a lived culture that is respectful and protective of these rights - a human rights culture (Campbell 1999; Gibson 2004; Palm 2015).

Despite having extensive and sophisticated legislature providing protection for all people, South Africans are still experiencing violations of their human rights on an everyday basis (Palm 2015:1). The xenophobic violence that swept the country in 2008 (see Sosibo 2015) and again in 2015 (see eNCA 2015), the 2011 open toilets issue in the Western Cape township of Khayelitsha (see Mail \& Guardian 2011), the illegal dismantling of shacks by the KwaZulu-Natal local government in 2009 (see Mail \& Guardian 2009) and the destruction of dozens of schools in Vuwani in 2016 (see Buccus 2016) are but a few examples of this. As evidenced by the above examples, while South Africa has a state-of-the-art Constitution with an enshrined Bill of Rights, it does not yet have a human rights culture necessary to ensure that these rights are part of the lived reality of all South African people (Campbell 1999; Gibson 2004; Palm 2015; Silk 1990; VillaVicencio 2005). Without South Africa building a culture that actively protects and enforces its rights, and all the responsibilities that accompany it, then this state-of-the-art human rights legislature is of little help.

\section{The Veracruz Declaration (2017)}

The responsibility for building a human rights culture is one that lies with all, including civil society organisations and universities. The recent Veracruz Declaration (Talloires Network 2017) supports this idea. Signed in Tufts European Centre in Talloires, France, the declaration aims to foster education, leadership and livelihoods. The declaration grew out of the Talloires Declaration of 2005 that aimed to strengthen both the civic role and social responsibility of tertiary institutions, pledging 'to promote shared and universal human values, and the engagement by our institutions within our communities and with our global neighbors' (Talloires Network 2005). The Veracruz Declaration was signed by over 280 participants, with representatives from 76 different tertiary institutions from over 31 different countries, at the Talloires Network conference that took place 21-23 June 2017.

The declaration opens by stating that 'we believe that higher education institutions exist to serve and to foster relationships with the society and communities of which they are a part' (Talloires Network 2017). It then recognises the changing landscape of tertiary institutions, who like the communities they are part of, are experiencing issues such as racism, growing social inequalities and the breakdown of social structures. In this context, the declaration affirms that education is a universal human right and that universities have the responsibility to promote and address this. Among other things, it declares that universities have a responsibility to 'promote access to knowledge and technology' and to promote communities and societies that are sustainable, with an equitable distribution of resources for this development. Furthermore, the declaration places emphasis on the responsibility of universities to be spaces where social responsibility and human dignity are advanced through engagement in higher education. It recognises that with rights come responsibilities and invites both the staff that work there as well as students and community members to take up these responsibilities in order to create university spaces that are human rights respective.

In the recent FMF protests, this has not been evident in institutional culture. The fees protests have predominantly comprised of students, with some concerned staff and community members, who have been calling for free, decolonised, Afrocentric, quality tertiary education for all. The movement also includes in its aims an end to rape culture and an end to the outsourcing of university workers. Booysen (2016:3) remarks on this as a protest that is concerned with the 'intersectionality of continuous societal injustice'. This protest is not only about a desire for the fall of certain things - tuition, rape culture and outsourcing - but it is also a protest for what is wanted. What is wanted is a better university community, one that works for its students in order for them to create a better future for all in South Africa (Godsell et al. 2016). In examining what the fees protests are calling for, it becomes clear that these are the very same desires of the Veracruz Declaration for tertiary institutional spaces. However, as evidenced by the fees protests, university and institutional cultures are not spaces that promote the right to education for all, nor is the institutional culture conducive to the promotion of a human rights culture. Furthermore, this is a responsibility that the students of university spaces are taking seriously and calling for in the form of the FMF movement.

\section{A call to critical engagement (2016)}

In light of this, there have been some creative attempts to fulfil the responsibility of creating universities as spaces respective of human rights culture. However, these attempts have been initiated by civil society groups and theologians, and not the university institutions per se, in an attempt to support the students' call for advancing a human rights culture on university campuses. One such attempt was a theological study document entitled A Call to Critical Engagement (The Callists 2016), composed and formulated by a group of concerned theologians and civil society leaders.

Drawing on the South African theological praxis tradition of 'kairos theology', 2 this document attempts to offer a theological reflection and response to the FMF protests on 2.For more on Kairos Theology, see Nolan (1994), Buttelli (2012) and Le Bruyns (2015). 
university campuses around the country. Kairos theology emerged out of the struggle for the end of the Apartheid regime in South Africa. It was a theological and prophetic response to what was being observed in the country at the time. Le Bruyns (2015:1) explains that kairos theology is a type of liberation theology that is conceptualised by many as theology needed in times of oppression. Critical theological reflection is vital in moments of struggle and in light of the recent FMF protests, it is now, more than ever, that a prophetic and liberation theological response is needed. However, despite this need, there has been very little theological or critical engagement with FMF. A Call to Critical Engagement is an exceptional example of a kairos theology for today engaging the concerns of the fees protests. The document was drafted as a study document with the intention that there would be space for it to be critiqued and strengthened as the discussion continued and other input was received. Furthermore, it is posed as a first document, with the vision that there will be more documents to follow as FMF continues and evolves.

The document was made available in October 2016, after the first wave of protests that took place at the beginning of 2016, and in the midst of the second wave of protests taking place in the second semester of the year. In the document, we can see the FMF protests framed in theological language that attempts to speak prophetically into the midst of the higher education crisis in South Africa. The document comprises five sections. The first section, 'We acknowledge', states what has happened, noting the pain, frustration and anger of black students as well as acknowledging the systems that have caused this pain (The Callists 2016:2). This is followed by the sections 'We mourn' and 'We confess' where the act of mourning is structured as an acknowledgement of what is wrong and confession is made regarding the complacency of the community, as well as an acknowledgement of the actions of individuals that have made them complicit in a system of oppression (The Callists 2016:2-3). The study document also makes special mention of the theological sins that need confessing. This is then followed by the sections 'We affirm' and 'Therefore we commit ourselves' as well as 'Therefore we plead the following'. Here, the document affirms what has been observed in the FMF protests and in so doing also begins to establish a counternarrative - one that counters the dominant hegemony that argues that the students are being emotional and overreacting (The Callists 2016:4). After affirming what has happened, the section of 'Therefore we plead for the following' makes an appeal for action to take place in other aspects of society involved in the movement (The Callists 2016:5). The final section is entitled 'In humility we pose these questions of invitation for on-going dialogue and reflective engagement' (The Callists 2016:6). In posing questions that attempt to offer space for ongoing dialogue and reflection, the document acknowledges that the exercise of critical reflection is not linear or a once-off process, but rather a continuous cycle.

Furthermore, the intention of the authors is for the document to be circulated widely and endorsed by members of the theological community within and beyond the higher education sector around the country and the world. In doing this, the document becomes part of the public discourse. It was made publically available for download, ${ }^{3}$ with close to 200 signatories from many different university institutions, church denominations and community organisations. Being endorsed by many members of a community allows the community to take public ownership of the document, thus making it a statement of position - of a community of people rather than just of one or two individuals. This is the articulation of a desire by the community for university spaces that honour a human rights culture much as the Veracruz Declaration has done.

\section{Indecent theology}

A theologian who is helpful in highlighting the importance of developing a human rights culture, as well as demonstrating the results should it not happen, is Marcella Althaus-Reid in her work, Indecent Theology. 'Indecent Theology' is a term coined by Marcella Althaus-Reid, a Latin American theologian born in 1952 and trained in Liberation theology. Althaus-Reid (2000) has, through this work, developed a form of queer theology that finds its point of departure at the point of intersectionality of Liberation theology and Queer theory, including in it elements of post-colonial thinking (AlthausReid 2000:2). Gerard Loughlin (2008:144) explains that queer theology is a form of theology that holds in tension two concepts related to the meaning of the word 'queer'. Theology is queer in the sense that the word queer means odd or strange and this theology is strange because it goes against the norms of society. However, theology is also queer 'because it finds like queer theory - that gay sexuality is not marginal to Christian thought and culture, but oddly central' (Loughlin 2008:146). Althaus-Reid's (2000:1) theology is a form of theology that asks questions about what is considered 'decent' and 'indecent', with particular reference to constructions of sexuality. Althaus-Reid (2000:2) explains that Indecent Theology is attempting to problematise constructions, in particular, sexual constructions, that oppress people.

Furthermore, this theology is attempting to strip away the layers of mythology that sustain the constructions of what is decent and what is indecent. Althaus-Reid (2000) writes:

Indecent Theology is the opposite to a sexual canonical theology, concerned with the regulation of amatory practices justified as normative by economic infrastructural models where anything outside hegemonic patriarchal heterosexuality is devalued and spiritually alienated. (p. 9)

It attempts to give voice to, and tell the stories of, those on the margins of society while reflecting critically on issues of faith from this perspective. Her argument is that every theology, regardless of its parameters, will consciously or unconsciously project a sexual praxis that codifies acceptable and unacceptable behaviour in society (Althaus-Reid 2000:4). She argues that traditionally, theology has constructed a sexual discourse that is based on heterosexual binaries that are 3.Available at: https://clintlebruyns.wordpress.com/2016/10/21/theologians-insouth-africa-respond-to-feesmustfall 
male-dominated. Furthermore, she remarks that discourses that are suspicious of traditional sexual constructions have not been readily introduced to religious, economic or political life. This, she argues, is no different in traditional Liberation theology that has been constructed as 'a (hetero) sexual idealist theology, based in the systematic traditions of the West' (Althaus-Reid 2000:23). These traditional discourses are overly concerned with regulating sexual behaviour and discourse but, she argues, these discourses are also 'decent' and 'acceptable' ones (Althaus-Reid 2000:22). However, this framing of sexual discourse as a heterosexual binary is not reflective of lived reality. In answer to this, Althaus-Reid (2000:64) argues that a theology that is 'indecent' and does not adhere to traditional binary constructions of life and sexuality is needed. This 'Indecent Theology' is one that will always speak from the margins, attempting to identify with the lived reality of people and not the accepted and artificial construction of an ideological representation of reality.

\section{Indecent theology and \#FeesMustFall}

Moving from but also beyond her immediate sexuality frame, Althaus-Reid (2000:64-65) explains that 'Indecent Theology' is a contextual theology. As such it is important to ask what an 'Indecent Theology' would look like in a South African context and, more specifically, what might it be for FMF. 'Indecent Theology' attempts to interrogate accepted constructions of the world and to represent them in ways that include voices from the margins. In light of this, it is a helpful theology to use for an analysis of the constructions around the FMF protests. The narrative of the FMF movement has been highly contested space, with many competing voices. Furthermore, this contestation has largely been dominated by the voices of those with power, like the university and news media. This has established a dominant, and accepted, view of the protests while at the same time neglecting the voices of others.

The work of Althaus-Reid in interrogating established narratives and recreating alternate ones will provide valuable insight into ways of interrogating the already established fees narrative. Furthermore, her work will inform the creation of new narratives that, instead of representing powerful voices, can represent the voices of the marginalised who in this case are the students. In order to explore this, themes will be drawn out of Althaus-Reid's Indecent Theology (2000) and examined, looking at how they apply to the context of FMF in PMB. Two different themes will be used: a theme of 'disappearances' and a theme of 'body'.

\section{Disappearances}

Throughout her work, Althaus-Reid (2000) develops the notion of disappearances. These disappearances take place through the construction of narratives that are not representative of people and their realities (Althaus-Reid 2000:25). One such example is the way in which the poor have been constructed within Christian meta-narratives. She argues that within Latin America, the poor have been treated as a homogenous group. The narrative constructed of the poor is a romanticised, idyllic version of poor people who are innocent or naïve and which sees them as asexual or virginal. This is the 'decent' narrative of who the poor are and what it is to be poor. However, she asks us to consider the poor transvestite who has to prostitute themselves for a living or the single woman fighting to become an ordained priest or the single mother selling lemons on the side of the road. She asks if these people could not also be understood as poor (Althaus-Reid 2000:32). As a result, to treat the poor as one homogenous group is already a denial of the lived reality of many people. Nevertheless, the construction of the poor as innocent, naïve or asexual became fashionable within Christian theology, but these representations are 'in fact fetishisations, reified phenomena extrapolated from the reality of people's lives, concepts which lost any relation to the context which produced them' (AlthausReid 2000:34). In constructing a narrative that is 'decent', the narrative created causes the erasure of the people who the narrative is supposed to represent. In so doing, the constructed narrative causes the realities of the poor to disappear leaving only a non-reality behind which vaguely resembles the lives of the poor. The result is the disappearance of people.

Furthermore, Althaus-Reid (2000:28) argues that in society, the law of ownership determines how a narrative is created and ownership most often resides with the powerful. In the case of the poor, she argues, they are turned into a commodity to be written about but they do not have the power or means to produce their own discourse. 'Decent' theology creates narratives that claim to represent the marginalised but which are in actual fact not representational of lived reality. As the oppressed and marginalised often do not have the means or the platform with which to create their own narrative, the dominant 'decent' narrative replaces them, in effect causing them to become invisible and disappear.

\section{Body theology}

Another theme that can be drawn out of the work of AlthausReid (2000) deals with theology of the body. Althaus-Reid (2000:18-19) argues that the Systematic Theology of the Western Grand Narratives is one that is constructed on a fictional understanding of the relationship between mind and body as a dualistic opposition. Very often, this relationship is skewed to favouring the mind over the body. However, when reading the Bible and doing theology, we are constantly confronted by bodily struggles. She remarks that Christian dogmatics find their foundation in these struggles and all of Christian faith appears to be related to such physicality. Examples of this can be seen in functions such as 'artificial insemination and the birth of Jesus-God, issues of control of sexuality, torture, hunger, death, and the return of the killed body in resurrection' (Althaus-Reid 2000:18). Not only is Christian faith about bodily functions, it is also about bodily relations. One of the examples used to illustrate this is that of the Trinity that, she argues, is a symbolic recreation of a medieval family's hierarchical structure. 
As a result, she concludes that the inclusion of a body dimension in theology is important in the act of theological analysis (Althaus-Reid 2000:19). In the first publication by Fallists themselves on the \#FMF movement - Rioting $\mathcal{E}$ Writing: Diaries of the Wits Fallists (2017) - this bodily dimension is among the common threads running through the various narratives under the rubrics of 'Spaces, tactics and (direct) action' (theme 1), 'Gender, power and identities' (theme 2), 'Student and worker solidarity' (theme 3) and 'Solidarities from beyond' (theme 4). Theological engagement on FMF cannot ignore or trivialise a body theology. Such 'bodily' aspects will be further uncovered in the case study to follow.

\section{A case study - University of KwaZulu-Natal Pietermaritzburg}

In light of the theological work of Marcella Althaus-Reid (2000), the next section will focus on one aspect of the UKZN PMB FMF narrative and its construction. There are many aspects that could be analysed; however, as the narrative is too large to fully analyse within the scope of this article, this section will instead focus on only one aspect of the PMB FMF protests. This aspect is that of the court interdict which will be explored in light of both the ideas of human rights and the themes of Althaus-Reid as set out above, in order to discover how 'Indecent Theology' might inform the debate about human rights culture on university campuses in light of FMF.

\section{Court interdict}

The court interdict as bearer of violence: Section 17 of the South African Bill of Rights protects the right of citizens to protest. It states that 'everyone has the right, peacefully and unarmed, to assemble, to demonstrate, to picket and to present petitions' (South African Government 1996). However, within the FMF narrative, this right has become contested space. When the protests began, a narrative around contending rights also began, with protesting students arguing their right to protest, while university structures and non-protesting students arguing their right to learn without disruption and fear (De Vos 2015; Duncan 2016). As a result, in order to prevent the students from protesting under the banner of FMF, UKZN took out a court interdict issued on 31 August 2016. This prevented UKZN students from either organising or participating in any protest, demonstration or gathering. The University of KwaZulu-Natal was by no means the only university to do so and they were continuing a trend of university interdicts against protesting students already established in the previous year with the \#RhodesMustFall movement and its calls for decolonisation (Godsell et al. 2016:104). Furthermore, Godsell et al. (2016:104) remark that this action allowed universities to bring police onto campuses and that the willingness of universities to do so 'speaks to the institution's initial intent to strong-arm and threaten students and staff to desist from protesting, as well as denying them full citizenship of the university'.

Jane Duncan (2016) writes that in many countries, it is considered socially unacceptable for police to enter university campuses as it is seen as a breach of the autonomy of a university. In the event of protests, she remarks, this may result in a university feeling unable to respond appropriately to protestors, which, in turn, may lead to an increase in securitisation and attempts to suppress protests. She notes that as a result of some protests having had violent elements, universities have performed exactly this. The University of KwaZulu-Natal was one such university, which, after obtaining a court interdict, introduced increased security, as well as private security in the form of Mi7 - and its tactical units - and the South African Police Service (SAPS) - with its community order policing unit - in order to enforce this interdict. ${ }^{4}$ Duncan (2016) notes that international human rights opinion is helpful in a discussion of this sort. She makes reference to a special report submitted to the United Nations on the right to protest and the proper management of assemblies (see Human Rights Council 2016), which was compiled by over 100 experts. This report upholds the freedom of assembly, including the right to protest, as an inalienable right facilitating democratic expression that holds those in power to account. They also argue that such protests, even if disruptive, must be tolerated and allowed because the risk to human rights is greater than the inconvenience of tolerating temporary disruption (Human Rights Council 2016:6). Furthermore, they argue that it is the duty of the state to facilitate peaceful protest, not suppress it (Human Rights Council 2016:10). Duncan (2016) remarks that often the threat of violence is used as a reason to suppress a protest - an institution like a university or the state uses the idea of imminent protestor violence as the excuse to end a protest. However, Duncan (2016) explains that the report makes it clear that the basis from which all parties should work is the presumption of peaceful protest. Therefore, these arguments for suppressing protest are unacceptable reasons for preempting or suppressing the right to protest.

The report also offers opinion on the use of force in protests. It says that 'force shall not be used unless it is strictly unavoidable, and if applied it must be done in accordance with international human rights law' (Human Rights Council 2016:12). Furthermore, it says that when force is used, its primary purpose should only be to de-escalate a situation but that, unless unavoidable, peaceful protest should not be interrupted. It adds to this saying that crowd control should not be enforced by the use of firearms or paramilitary units, because these are trained in the use of maximum force (Human Rights Council 2016:12). Within the landscape of UKZN PMB, the introduction of the university's interdict against students brought trauma and violence onto the UKZN PMB campus. This has been in the form of security and policing tactical units, smoke grenades, rubber bullets and injury to persons; as well as the answering violence of students, such as stone throwing in response to the increased security measures. As a result, it can be seen that introducing a court interdict into the university landscape has also introduced violence into the FMF protests. Not only has the interdict been used as a means of preventing and suppressing protest, but the manner in which this has been done has been 4.See official communication from UKZn (Seshoka 2016; Van Jaarsveld 2016a; 2016 b). 
through violence such as rubber bullets and teargas (see Wicks 2016a; 2016b; Wicks \& Areff 2016). Furthermore, many of the expressions of protest undertaken by UKZN PMB FMF have been attempts at peaceful and creative protest - some examples being attempts to host community discussions on campus, silent protests and political education classes - all of which were suppressed by armed security forces (see Umraw $2016 b ; 2016 c)$. These overreactions on the part of universities and security forces have only 'escalated the situation and fuelled protestor counter-violence' (Duncan 2016).

The constitutional law scholar, Pierre De Vos (2015), reflecting on the relationship between the right to protest and the events of FMF, argues that it is morally indefensible for a university to obtain and enforce an interdict through brutal police violence. Furthermore, he argues that, in a democracy where the right to protest has been enshrined, it is morally wrong to break up a demonstration that is largely peaceful. He notes that the argument has been used by universities, and other players, that the protests have threatened and infringed on the rights of other students who want to attend classes and the right of the university to not have its property damaged. ${ }^{5}$ However, he writes that 'in the absence of any real threat to person or property, any use of force to break up a protest will constitute a disproportionate response to the limitation of other rights' (De Vos 2015). He argues that the willingness of both the state and institutions like a university to use force to suppress protest signals 'a callous disregard for the equal worth of human beings who happen to have less power than yourself ${ }^{\prime}$ (De Vos 2015). In light of this, the arguments by universities that the interdict and its accompanying securitisation is necessary in order to protect the university and the public is not in line with international human rights norms and standards and is a violation of the human rights of students. This violation of human rights is indicative of a university institutional culture that is not respective of the rights of all.

The court interdict as violent: In light of the framework of Althaus-Reid (2000), the introduction of a court interdict against protest can be understood in terms of the theme of disappearances. Duncan remarks that universities should be setting an example for the broader society by being arenas where free intellectual thought is both embraced and encouraged (Duncan 2016); this idea is echoed by both the Talloires Declaration (Talloires Network 2005) and the Veracruz Declaration (Talloires Network 2017). However, the introduction of a court interdict into this environment severely impedes the development and promotion of a culture that encourages intellectual thought. An interdict that prevents or limits protest indicates to those who are protesting that their dissenting voices are not welcomed or allowed within the discourses of the university.

Pillay (2016:157) writes that this type of schism between theory - in this case, the theoretical belief that universities should be places that encourage free speech - and practice the university's interdict and suppression of protest - create forms of institutional silence and silencing. This silencing, he argues, is violent psychologically, inflicting harm on the oppressed who need advocates. Furthermore, Althaus-Reid (2000:12) explains that grand narratives are the narratives that are used to construct the way we see the world. However, these narratives are not neutral in their construction and can also be a way of commodifying life and investing some with power while robbing others of it. Within the FMF protests, the court interdict is the tool that is used to construct and impose such a grand narrative onto the landscape of the protests. The construction of this narrative places the university in a position of authority and the students or protestors in a subordinate position. Furthermore, being in possession of a piece of legislation that supports a particular viewpoint could also be seen as the law supporting the possessor of the interdict.

The moral construction of this narrative is then that the university is in the right, while the protestors are in the wrong. In light of an interdict, all protest that happens after the legislation is attained is then illegal and therefore wrong at least inside the university premises. Furthermore, this type of narrative constructs a dialogue that implies that if all protest that takes place when there is an interdict is wrong, then the protest and what is being protested must be wrong too. If it is wrong, then the protestors no longer need to be listened to and any means used to prevent them protesting is justified. The court interdict gives birth to the creation of a grand narrative that frames the university as having the moral power to suppress, and silence, illegal protests. This narrative is created as a binary with the university being portrayed as right and the students as wrong. By framing the discourse as a binary, the grand narrative fails to take into account the complexity of the FMF protests and its relationship with the university. ${ }^{6}$ Such a narrative causes the disappearance of the students and the cause that they are fighting for and allows the university's violation of the student's right to protest to be justified as the accepted, right way of doing things.

Court interdict as violating: The end to rape culture is one of the central aims of the PMB FMF campaign (UKZN FeesMustFall Collective, Facebook post, 12 September 2016). The Bill of Rights protects the freedom and security of each person. In particular, it states that every person has the right 'to security and control over their body' and the right 'to be free from all forms of violence from either public or private sources' (South African Government 1996:6). However, the introduction of the court interdict into the university landscape has nurtured a violent and violating culture within the university. This is evidenced by the rape of a UKZN PMB student during the FMF protests. Rape and sexual harassment are very clear violations of the right of an individual to be free of all forms of violence and to have security and control over their own body. In the instance of the rape of a UKZN

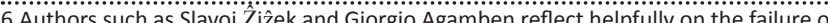
demor such and the Ziẑ̀ the world is experiencing. Furthermore, they reflect on the use of power to impose the world is experiencing. Furthermore, they reflect on the use of power to impose the perspective of the owners of capital onto the populace. This is part of the macro-reality within which the FMF movement takes place. 
PMB student (see Singh 2016; Umraw 2016a), allegedly raped by a member of the SAPS while involved in an FMF activity, UKZN agrees that rape is a violation of human rights. In regard of this specific instance, the university states that it:

condemns violence against women in all its forms, including physical, sexual, and psychological. Rape and sexual abuse are a grave violation of women's human rights and are never justified. The University does not condone any form of brutality to any sector of society including students. (Van Jaarsveld 2016b:2)

In light of Althaus-Reid's (2000) conceptualisations of body theology, on the simplest level, rape is a violation of the body, and it is a struggle of bodies where one struggles for dominance over another. This is a physical violation that echoes other bodily violations running through the narrative of the biblical sacred texts. An example of such as violation, according to Althaus-Reid (2000:39), is Mary and the conceiving of Jesus. Mary did not consent to being pregnant; she did not have control over her body in this which happened to her. As a result, her pregnancy could be understood as a violation of her bodily rights. The incident of a PMB student being raped by a police officer is unequivocally a violation of body and thus a human rights violation.

However, in this instance, critical theological reflection using Althaus-Reid's (2000) work around disappearances reveals further violations. Althaus-Reid (2000:23-24) argues that the entire biblical text is concerned with sexual control and that this thread runs alongside, and intertwined with, discourses of power. Western Christian narratives have constructed an unambiguously, biologically male god. The construction of the Trinity is of God the Father, God the Son and God the Holy Spirit. While there are constructions other than God as male (see, for example Ruether 1998), the predominant view within society is God as the ideal heterosexual (white) man (AlthausReid 2000:18). This construction of a male God impacts the construction of Mary too. It turns Mary into nothing more than the silent carrier of the Word of God. She is the carrier of male seed (Althaus-Reid 2000:69). Through this construction, Mary disappears as an actual person and is silenced. Just as a heterosexual, male construction of theology causes Mary to disappear, an examination of the construction of the narrative surrounding this rape case reveals that these narratives, too, have caused the silencing and disappearance of the student who was raped, causing further violation of that student. During the fees protests, the landscape of communication has been dominated by the mainstream news media and official university documentation (Godsell et al. 2016:103). This domination of the landscape of official communication gives power to journalists and the university structures to shape and create the dominant narrative as they choose.

Such domination extends to the narrative of the student raped. The university issued a statement which contained a condemnation of rape and violence against women. However, the paragraph in which this condemnation is given is under the heading 'Erroneous reporting of an alleged rape' (Van Jaarsveld 2016b). Furthermore, the lines condemning the rape are preceded by a paragraph that states that the university had received a report of a student being raped. When the rape is written about, it is referred to as an 'alleged incident' and says that they (the UKZN) have been informed that the student had laid a charge with the police. The official university communication then says that the incident happened off-campus and that there has been no report of a rape on-campus. The official communication then ends stating that 'the media are urged to ensure the veracity of claims and students are cautioned to guard against making defamatory comments and spreading disinformation' (Van Jaarsveld 2016b).

The newspaper articles published about the rape use the same language describing an 'alleged' rape, as well as reporting the university's official stance that the rape occurred off-campus (see Singh 2016; Umraw 2016a). However, the manner in which the university's position was reported gives the impression that the rape did not actually occur. The university could have condemned the rape and defended the student even had the rape occurred off-campus without creating the impression that the rape never occurred. In effect, while making a statement condemning rape in general, the university has used its position and power to create a statement that invalidates the content of the statement itself. In stating that the rape was alleged and that it had been erroneously reported, the university has created a narrative that denies that the rape even happened. This denial invalidates the raped student's experience of violation, thus silencing her and attempting to cause her to disappear from the narrative altogether.

This is just one among many instances where the introduction of a court interdict into the university community has brought with it circumstances and consequences violating to those in the community. This invalidation is in itself a violation of the integrity and dignity of protesting students and in no way contributes to the creation of a human rights culture on the university campus.

\section{Conclusion}

Most people will agree that human rights are important; however, these rights are not always experienced in the lived reality of all people. As a result, what is needed is the development of a culture that is respective and protective of the rights of all people. The recent Veracruz Declaration (Talloires Network 2017) is in agreement with this, establishing that universities and tertiary institutions should be spaces where social responsibility and human dignity are both embodied and taught. This same sentiment is recognised in the attempt by theologians and civil society to engage the university around the fees protests in the form of the study document A Call to Critical Engagement (The Callists 2016). However, from the examination of the court interdict as the bearer of violence, as violent in itself and as violating within the arena of the fees protests, it has become clear that there have been human rights abuses. The university has used its institutional power to silence students through obtaining a court interdict. This violation prevented, and continues to 
prevent, ${ }^{7}$ students from expressing their constitutionally protected right to protest. Nevertheless, the argument has been made that the university, like many other universities around South Africa, is using the interdict to protect the rights of those wanting to learn as well as for the public good. However, De Vos (2015) argues that:

as long as such protests remain peaceful and as long as they pose no immediate threat to persons or property, it is morally unconscionable to use force to break them up - no matter how inconvenient the protest may be for others. (p. 1)

The contribution of Indecent Theology to this discussion is in the critical analysis of the human rights abuses. Through the lens of this theology, the construction of narratives that contribute to the abuse of rights becomes obvious. It becomes clear that the court interdict created a narrative that placed the university in the position of moral justifiability while placing the protesters in opposition to this. This narrative also allowed the university to justify increasing security and bringing police onto campus. These acts caused the increase in violence on campus, with the violent suppression of the many non-violent and creative protest initiatives undertaken by FMF. Furthermore, the construction of a narrative that denied the rape of a student at the university served to add another layer of violation to what had already taken place. This violation, and the manner in which the narrative was framed, caused the silencing of someone whose rights had already been violated. The conclusion that can be reached is that there have been abuses of human rights that have been evident in the FMF protest with very little evidence of a human rights respective culture within the culture of university institutions.

Using the language of liberation theology, and in light of the Indecent Theology analysis conducted above, it is clear that theological affirmation of the FMF students is needed. If God is on the side of the poor and the oppressed (Boff \& Boff 1987), then in this instance, the poor are the protesting students. It is the role of theology in the FMF protests to be the voice reminding the powerful of this and in so doing helping to challenge and change the prevailing university institutional culture to one that is rights respective and centred around a discourse of human dignity and social responsibility. In so doing, theology will be positively contributing to the protection of the rights of all and the growth of a human rights respective culture within South African universities and the broader society.

\section{Acknowledgements Competing interests}

The authors declare that they have no financial or personal relationships which may have inappropriately influenced them in writing this article.

\footnotetext{
7.It should be noted that the court interdict remains in place, available to the university to use should they wish to do so. Furthermore, the results of this interdict are still being experienced by students who are facing court charges as well as financial and academic exclusion from the university as a result of being interdicted. See also the petition calling for the university to protect these students from a ruined future: petition calling for the university to protect these students from a ruined future:
https://awethu.amandla.mobi/petitions/ukzn-council-and-executive-must-protecthttps://awethu.amandla.mobi/pe
}

\section{Authors' contributions}

L.G. and C.L.B. equally contributed to the research and writing of this article.

\section{References}

Althaus-Reid, M., 2000, Indecent theology, Routledge, London.

An-Na'im, A. \& Deng, F., 1990, 'Editors preface', in A. An-Na'im \& F. Deng (eds.), Human rights in Africa: Cross cultural perspectives, $\mathrm{pp}$. $\mathrm{xi-}-\mathrm{xv}$, The Brookings Institution, Washington, DC

Boff, L. \& Boff, C., 1987, Introducing liberation theology, Burns and Oates, Kent.

Booysen, S., 2016, 'Introduction', in S. Booysen (ed.), Fees must fall, pp. 1-22, Wits University Press, Johannesburg.

Buccus, I., 2016, Understand the burning of schools in \#Vuwani, viewed 17 July 2017, from http://www.iol.co.za/mercury/understand-the-burning-of-schools-invuwani-2023671

Buttelli, F.G.K., 2012, 'Public theology as theology on Kairos: The South African Kairos document as model of public theology', Journal of Theology for Southern Africa 143, 90-105.

Campbell, T., 1999, 'Human rights: A culture of controversy', Journal of Law and Society 26(1), 6-26. https://doi.org/10.1111/1467-6478.00112

Chinguno, C., Kgoroba, M., Mashibini, S., Masilela, B.N., Maubane, B., Moyo, N. et al., 2017, Rioting \& writing: Diaries of the wits fallists, SWOP - Wits University, Braamfontein.

Cmiel, K., 2004, 'The recent history of human rights', The American Historical Review 109(1), 117-135.

De Vos, P., 2015, \#FeesMustFall: On the right to mass protest and the use of force by police, Constitutionally Speaking, viewed 26 October 2016, from http://www. constitutionallyspeaking.co.za/feesmustfall-on-the-right-to-mass-protest-andthe-use-of-force-by-police/

Duncan, J., 2016, 'Universities must uphold the international right to protest', University World News, 25 November, viewed 26 October 2016, from www. universityworldnews.com/artivle.php?story $=20161125062441950$

eNCA, 2015, Xenophobic violence echoes deadly 2008 precedent, viewed 17 July 2017, from http://www.news24.com/SouthAfrica/News/Xenophobic-violence-echoesdeadly-2008-precedent-20150419

Gibson, J.L., 2004, 'Truth, reconciliation, and the creation of a human rights culture in South Africa', Law \& Society Review 38(1), 5-40. https://doi.org/10.1111/j.00239216.2004.03801001.x

Godsell, G., Lepere, R., Mafoko, S. \& Nase, A., 2016, 'Chapter 5: Documenting the revolution', in S. Booysen (ed.), Fees must fall, pp. 101-124, Wits University Press, Johannesburg.

Human Rights Council, 2016, Joint report of the Special Rapporteur on the Rights to Freedom of Peaceful Assembly and of Association and the Special Rapporteur on Extrajudicial, summary or arbitrary executions on the proper management of assemblies, United Nations General Assembly, Volume A/HRC/31/66, pp. 1-23, viewed n.d., from http://www.ohchr.org/EN/HRBodies/HRC/RegularSessions/ Session31/Pages/ListReports.aspx; https://documents-dds-ny.un.org/doc/UNDOC/ GEN/G16/018/13/PDF/G1601813.pdf?OpenElement

Ishay, M., 2004, The history of human rights: From ancient times to the globalization era, University of California Press.

Le Bruyns, C., 2015, 'The rebirth of Kairos theology and its implications for public theology and citizenship in South Africa', Missionalia 43(3), 460-477. https://doi. org/10.7832/43-3-131

Loughlin, G., 2008, 'What is queer? Theology after identiy', Theology Sexuality 14(143), 143-152. https://doi.org/10.1177/1355835807087376

Mail \& Guardian, 2009, Court rules KZN mass eviction law unconstitutional, viewed 17 July 2017, from https://mg.co.za/article/2009-10-14-court-rules-kzn-masseviction-law-unconstitutional

Mail \& Guardian, 2011, City of Cape Town loses open-toilet battle, viewed 17 July 2017 from https://mg.co.za/article/2011-04-29-city-of-cape-town-loses-opentoilet-battle

Nolan, A., 1994, 'Kairos theology', in J. W. De Gruchy \& C. Villa-Vicencio, Doing theology in context: South African perspectives, Orbis Books, Cape Town, pp. 212218

Palm, S., 2015, 'Reimagining the human? Re/constructing human rights?', Unpublished doctoral thesis, University of KwaZulu-Natal.

Pillay, S., 2016, 'Silence is violence: (Critical) psychology in an era of rhodes must fall and fees must fall', South African Journal of Psychology 46(2), 155-159. https:// doi.org/10.1177/0081246316636766

Ruether, R. (ed.), 1998, Religion and sexism: Images of women in the Jewish and Christian traditions, Wipf and Stock Publishers, Eugene, OR.

Seshoka, L., 2016, 'Communique from the Office of the Executive Director: Corporate relations: Moring update: Student protest', UKZN, 20 September, viewed 22 September 2017, from www.facebook.com/UKZN1

Silk, J., 1990, 'Chapter 12: Traditional culture and the prospect for human rights in Africa', in A. An-Na'im \& F.M. Deng (eds.), Human rights in Africa: Cross cultural perspectives, pp. 290-328, The Brookings Institute, Washington, DC.

Singh, K., 2016, 'Anc condemns UKZN violence', News24, 9 September, viewed 11 September 2016, from http://www.news24.com/SouthAfrica/News/anc-condemnsukzn-violence-20160906 
Sosibo, K., 2015, Xenophobia: What did we learn from 2008? viewed 17 July 2017, from https://mg.co.za/article/2015-04-23-xenophobia-what-did-we-learn-from-2008

South African Government, 1996, South African Government, viewed 05 May 2015 from http://www.gov.za/documents/constitution-republic-south-africa-1996

Talloires Network, 2005, Tufts University: Talloires network, viewed 05 July 2017, from http://talloiresnetwork.tufts.edu/who-we-are/talloires-declaration/

Talloires Network, 2017, Tufts University: The talloires network, viewed 05 July 2017 from http://talloiresnetwork.tufts.edu/blog/2017/06/15/the-veracruz-declaration/

The Callists, 2016, A call to critical engagement, South Africa, viewed 10 October 2016, from https://clintlebruyns.wordpress.com/2016/10/21/theologians-insouth-africa-respond-to-feesmustfall

UKZN, 2016, UKZN, viewed 04 December 2016, from www.registrar.ukzn.ac.za/ sessional-dates-2016

Umraw, A., 2016a, 'False and doubtful claims cloud UKZN student protest', The Witness, 8 September, viewed 13 October 2016, from http://www.news24.com/ SouthAfrica/News/false-and-doubtful-claims-cloud-ukzn-studentprotest-20160907

Umraw, A., 2016b, 'UKZN lectures arrested for "Doing Artwork"', The Witness, 25 October, viewed 25 October 2016, from http://www.news24.com/SouthAfrica/ News/arrested-for-doing-artwork-20161024

Umraw, A., 2016c, 'UKZN prayer meeting cut short by police', The Witness, 5 October, viewed 10 October 2016, from www.news24.com/SouthAfrica/News/ukznprayer-meeting=cut-short-by-police-20161004
Van Der Ven, J., Dreyer, J. \& Pieterse, H., 2000, 'Attitudes towards human rights among South African youth', Religion \& Theology 7(2), 111-141. https://doi. org/10.1163/157430100X00018

Van Jaarsveld, A., 2016a, 'Vice-chancellor's communique', UKZN, 6 September, viewed 29 September 2016, from www.facebook.com/UKZN1

Van Jaarsveld, A., 2016b, 'Vice-chancellor's communique', UKZN, 16 September viewed 29 September 2017, from www.facebook.com/UKZN1

Villa-Vicencio, C., 2005, 'God, the devil and human rights: The South African perspective', in E. Bucar \& B. Barnett (eds.), Does human rights need God? pp. 225-242, Wn. B. Eerdmans Publishing Co., Grand Rapids, MI.

Wicks, J., 2016a, 'Cops, security use paintball and rubber bullets against UKZN students', News24, 17 August, viewed 13 October 2016, from http://www. news24.com/SouthAfrica/News/cops-security-use-paintball-and-rubber-bulletsagainst-ukzn-students-20160817

Wicks, J., 2016b, 'Pricate security raids UKZN PMB Res', News24, 26 September viewed 15 October 2016, from http://www.news24.com/SouthAfrica/News/ private-security-raids-ukzn-pmb-res-20160926

Wicks, J. \& Areff, A., 2016, 'Teargas, rubber bullets and stun grenades fly as police clash with UKZN PMB students', News24, 22 September, viewed 15 October 2016, from http://www.news24.com/SouthAfrica/News/teargasrubber-bullets-and-stun-grenades-fly-as-police-clash-with-ukzn-pmbstudents-20160922 